\title{
GENERAL ANATOMICAL OBERVATIONS UPON THE AFRICAN CATFISH (CLARIAS GARIEPINUS)
}

\author{
Gheorghe Radu BOLOGAN*, PhD Student
}

\begin{abstract}
In order to acquire better knowledge of the morpho- physiological features of the African Catfish there have been done dissections on a varios number of fish of different sex, age, weight.
\end{abstract}

Keywords: Clarias Gariepinus, anatomy, African Catfish.

\section{Material and Method}

Eleven male fish have been dissected as following:

- three male weighing150gr

- four male of 800gr

- two male of $1200 \mathrm{gr}$

- two male of 500gr

Female - six weighing between 500-800gr

- three 800-1200gr

- three 1200-2000gr

Dissection on the ventral abdominal side with observations upon the main features of the organs and apparatus.

\section{Results and Debates}

The anatomical and physiological features make the African Catfish suitable for an intensive artifical breeding on a large scale in artificial aquacultures of small capacity.

The Anatomy and Physiology of the African Catfish.

General Observations on the Anatomy of the African Catfish

On dissecting the abdominal cavity on the ventral - median side we can observe:

- About $90 \%$ of the cavity is filled with fat tissue situated in parallel longitudinal fascicle,

- Stomach, liver, duodenum bulb and the area near the intestine are situated towards the cephalic extremity,

* S.C. Incavet S.R.L., Oradea, e-mail: gheorghe_bologan@yahoo.com

Cluj Veterinary Journal, 15(1)/2009, pp. 77-79 
- Excepting the liver, there is a disproportion between the weight which is very big and the reduced dimensions of the digestive organs (cavity, lumen, stomach, intestine),

- The oral cavity is extremly large compared its role as a digestive organ, as well as a respiratory organ (branchial filter),

- The bucal - oesophagus cavity is large, the oesophagian lumen larger and the stomach extremly small (almost having the dimension of the oesophagus; intestinal lumen is reduced),

- Has a stomach-omnivorous species,

- The liver is a soul organ with two lobes (at other fish species there more lobes),

- The pancreas has grape-shaped spread acinus,

- The intestine has a spiral first part then an even, descendent-short and reduced lumen,

- The existence of the gills and of the arborescent oragan-pseudopulmon,

- The kidneys are situated in the backhead under the pectoral fin, in a muscular chamber, strongly capsulated,

- Reduced heart situated under the oral cavity,

- The central nervous system includes the brain and the spinal marrow and the external nervous system includes nerves and two rows of ganglions situated on both sides of the backbone,

- Pneumatic bladder (fins) heads' end, arboral brain pan,

- The existence of a transverse cavity situated after the fin.

\section{Conclusions}

The African Catfish-clarias gariepinus is a fish species that posseses a lot of anatomical and physiological features from which I will mention the following:

- it has a complementary breathing apparatus-pseudolung, which allows this type of fish to make the necessary exchange in order to breath even in high turbidity level of the water with a low oxygen level. If the oxygen level in the water is reduced this fish lifts itself above water and fills its branchial chamber with air, emerging underwater it can keep the air in this chamber for a long time,

- outside the water this fish produces a large quantity of mucus at skin level in order to keep it moist and breath through. This process allows it to survive a long period of time on land,

- This omnivorous species has a rapid growing system and holds out various life conditions,

- It can be bred in tanks, in closed spaces with thermostat and water pomps keeping it under constant supervision and medium parameters,

- Due to its respiratory features it can be bred in large masses,

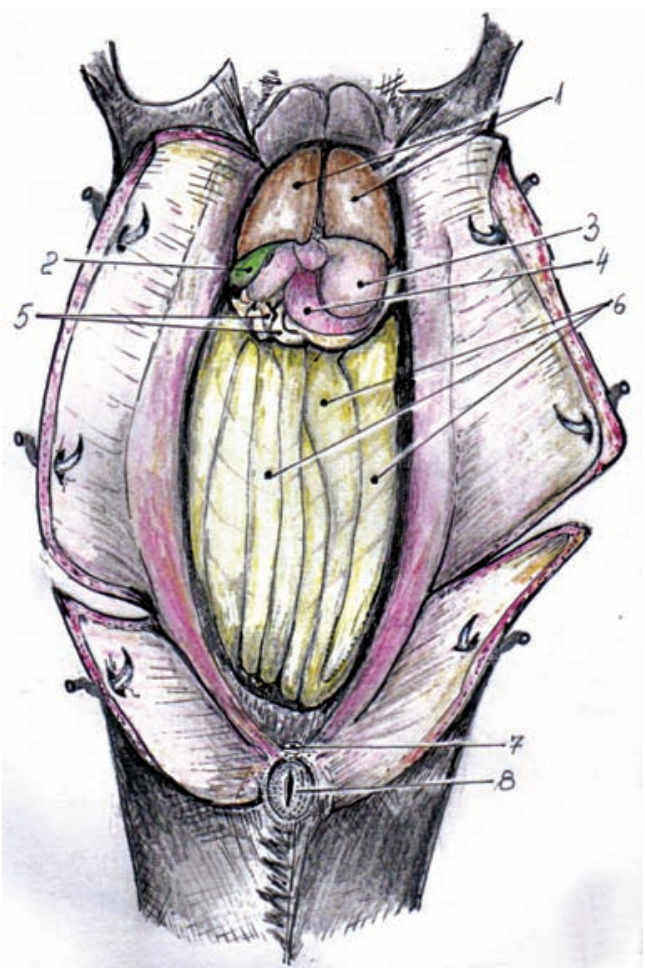

Anatomo- topographic aspect of organs in the abdomen after opening the ventral wall

1-Liver, 2-Bladder gall, 3-Stomach, 4-Pre-pyloric (gastro piloric) antrum of intestine, 5-Intestine (instestinal anse), 6-Fat tissue, 7-Anus, 8-Uro genital papilla 


\section{Reference}

1. Adriens D., W. Verraes, Neth J Zool, Growth of the Suspensiorial and opercular muscles in Clarias gariepinus (Siluroidei, Claridae), 1997.

2. Adriens D., W. Verraes, Neth J Zool, Growth in siluriform chondocrania, a case study of Clarias gariepinus ( Burchell, 1822), 1997.

3. Bănărescu, P.C., Fauna R.P.R. Pisces Osteichthyes, Editura Academiei Române, 1964.

4. Brehm Alfred, Lumea animalelor, Traducere, 1965.

5. Bud I., Diaconescu Ş., Mudura M, Creşterea crapului şi a altor specii de peşti Editura Ceres, Bucureşti, 2004.

6. Bud I., Piscicultura - Caiet de lucrari practice - Tipo Agronomia Cluj-Napoca, Acvacultura - Curs universitar, Tipo Agronomia Cluj-Napoca, 1999.

7. Cavaco Jeb, Vilrockx C, Trudeau Vl., American Journal of Phisiology - regulatory pubertal development of male African Catfish, Clarias gariepinus.

8. Deceuninck, V., National Reviews for Aquaculture development in Africa. No 15, Congo, FAO Fisheries Circular (770.15), in French, 1988.

9. Hegy A., Az afrikai harcsa, Elet es tudomany - Budapest, 2000.

10.Hogendoorn H., The African catfish a new species for aquaculture - Revista aquacultura, 1992.

11. Huet M. Traite de pisciculture, Ed. Wyngant Bruxelles, 1970.

12.Huet, M., Textbook of fish culture. Fishing Books ltd, Surrey, England, 1972.

13.Popovici I. şi col., Tratat de anatomie comparată Splanhnologie, Ed. Academie Pres, Cluj- Napoca pag. $26-55 ; 93-222 ., 2002$ 